\title{
Social Impact Analysis of Urban Riverfront Regeneration: River of Life (RoL), Kuala Lumpur City Hall (KLCH)
}

\section{Nuranisa Huda Ramlan, M. Zainora Asmawi, Mariana Mohamed Osman, Muhammad Faris Abdullah}

Department of Urban and Regional Planning, Kuliyyah of Architecture and Environmental Design, International Islamic University Malaysia, Jalan Gombak, Gombak, 53100, Kuala Lumpur, Malaysia

anisahudalan@gmail.com, zainora@iium.edu.my, mariana@iium.edu.my, mfaris@iium.edu.my $+60173342884$

\begin{abstract}
The River of Life (ROL) is a riverfront regeneration project that aims to transform the Klang River into a vibrant waterfront with high economic value. The study aims to define the implications of the RoL towards society in the area of KLCH. One hundred fifty respondents of local and international visitors completed the survey. From the findings, it shows that the respondents reacted favorably to all of RoL's social consequences, but improvements from the aesthetic and awareness is needed. These results help to maximize economic growth, enhancing social interaction and environmental preservation, especially in the urban.
\end{abstract}

Keywords: Riverfront regeneration; social impacts; River of Life (RoL)

eISSN: 2398-4287 @ 2019. The Authors. Published for AMER ABRA cE-Bs by e-International Publishing House, Ltd., UK. This is an open access article under the CC BYNC-ND license (http://creativecommons.org/licenses/by-nc-nd/4.0). Peer-review under responsibility of AMER (Association of Malaysian Environment-Behaviour Researchers), ABRA (Association of Behavioural Researchers on Asians) and cE-Bs (Centre for Environment-Behaviour Studies), Faculty of Architecture, Planning \& Surveying, Universiti Teknologi MARA, Malaysia. DOI: https://doi.org/10.21834/e-bpj.v4i12.1854

\subsection{Introduction}

Water resources have a vital role to play in most parts of the world throughout the histories in the establishment or formation of new settlements of a habitat. However, in the advent of urbanization, globalization, and technology era, the relationship between the water ecosystem and humans is interrupted due to some changes made to make way for economic activities. The ecosystem has changed, pressured, and degraded as the human population grows over the years (Deng et al., 2015). The River of Life (RoL) project is the fifth Entry Point Project (EPP) identified in the Greater Kuala Lumpur/Klang Valley National Key Economic Area (NKEA) under the Economic Transformation Program (ETP). The project aims to convert the Klang River into a vibrant and livable waterfont with high economic value. The Klang River is a natural asset of Kuala Lumpur and Klang Valley comprising components of heritage center and historical significance with a strategic location within the city center. The three main parts of the project are River Cleaning, River Beautification, and River Development. Each component of the project was initiated from 2011 up until now and will continue until 2020.

Klang River was chosen for the River of Life program because it is the main river that flows across the Kuala Lumpur city areas. The water quality of Klang River has been moderately polluted ever since 2004, hence there is a need to upgrade the environmental quality through this riverfront restoration program. Also, there is a hidden potential for economic growth and a better Quality Of Life (QoL) beneath the underutilized urban landscape of the city. Water quality is just as crucial for satisfying basic human and environmental needs yet, has received less investment, scientific support, and public attention.

eISSN: 2398-4287 @ 2019. The Authors. Published for AMER ABRA cE-Bs by e-International Publishing House, Ltd., UK. This is an open access article under the CC BYNC-ND license (http://creativecommons.org/licenses/by-nc-nd/4.0). Peer-review under responsibility of AMER (Association of Malaysian Environment-Behaviour Researchers), ABRA (Association of Behavioural Researchers on Asians) and cE-Bs (Centre for Environment-Behaviour Studies), Faculty of Architecture, Planning \& Surveying, Universiti Teknologi MARA, Malaysia. DOI: https://doi.org/10.21834/e-bpj.v4i12.1854 


\subsection{Purpose of the Study}

The study analyzes the perception of the community towards the implementation of the RoL riverfront regeneration program. The result will be used to determine the successfulness of the program from the social aspect to create a highly sustainable future for Kuala Lumpur and future efforts. RoL is essential to the community as four out of eight objectives were targeted towards the community, which are; to promote transit nodes, to increase the economic value of the river, to revitalize social and cultural heritage, and lastly to promote environmental awareness among the community.

\subsection{Objectives of the Study}

In line with the purpose, the objectives of the study were to analyze the impacts of waterfront regeneration on aesthetic, QoL, and sociocultural elements in the municipality of Kuala Lumpur City Hall and to give suggestions and recommendations towards approaches for the betterment of waterfront regeneration program.

\subsection{Literature Review}

In definition, the waterfront is an area where the interchange of activities happens, and it is a valuable resource where it connects the land, water, sun, air, and productive plants (Tumbde, 2005). Besides, according to Zhang (2002), the waterfront is where the land meets the water that appeals to people. In conclusion, the definition of riverfronts is any building that has a mere visual and physical connection to the water. The city-river relationship combines to create social impacts such as enhancement in aesthetic value, increasing the QoL, and improvement of socio-cultural elements in the area.

\subsection{Aesthetic Values}

The importance of aesthetic values in regeneration projects is supported by Palermo (2014), who stated that place-making processes could have a significant influence on social inclusion in communities. Next, Timur (2013) reported that the categories to measure aesthetic values are visual, audial, and tactual effects. Krause (2001) argued that a total image of a landscape does not only limited to physical and structural aspects but also the visual and cultural aesthetic expression of the view. Onen (2007) mentioned that the addition of water in urban spaces is created to serve as a barrier or buffer to artificial sound by creating a natural soundscape. The tactual effect is the communication of human beings with water. If the river water is clean and safe enough to be touched or played with, it creates a sense of serenity in some religious beliefs.

\subsection{Quality of Life (QoL)}

A healthy environment should encourage physical activities and social interaction that will influence the physical and mental health of an individual. QoL in an urban quality can be measured accordingly through these indicators; use and fruition, health and well-being, and appearance (Garau \& Pavan, 2018; Rabe, 2018). The area of the restoration site should be walkable enough to enhance the attractive and enjoyable views and vista while promoting economic development opportunities in the area. Continuous pedestrian and bicycle lanes could invite more physical activities to a particular area (Glasson \& Wood, 2009). The two main elements that contributed to the appearance in the QoL is the environment and built-environment characteristics. Also, Streimikiene (2015) stated that the provision of facilities and amenities is significant to the success of a river restoration project. Pocket parks, gazebos, sitting benches help create an activity and invite more opportunities for social interaction in the area.

\subsection{Socio-cultural element}

In many restoration projects, people often overlooked the importance of socio-cultural factors. To come out with a more sustainable river restoration project, stakeholders need to give equal considerations to the socio-cultural factors surrounding the urban area. Wu, Huang, and $\mathrm{Yu}(2013)$ stated that the eco-system services and culture relationship had become a rising trend that focuses on the relationship between society and nature. One of the successful river restoration projects incorporated promoting historical and cultural tourism as one of their objectives (Jun \& Kim 2011).

\subsection{Methodology}

\subsection{Study Area}

Klang River Basin is the fourth largest basin following Sungai Langat, Sungai Selangor, and Sungai Bernam. The stretch of $120 \mathrm{~km}$ streams fall under the jurisdiction of Kuala Lumpur and Selangor. This study focused on the Klang River and its tributary, Gombak River, which flows under the municipality of $\mathrm{KLCH}$. Kuala Lumpur is the city with the most population density in the land area of 242.2 square kilometers. In 2009, 1.7 million populations were living in the city, and the number is projected to be 2.2 million in 2020 . The six strategic zones of Kuala Lumpur are; City Center, Wangsa Maju-Maluri, Sentul-Manjalara, Damansara-Penchala, Bukit Jalil-Seputeh, and Bandar Tun Razak-Sungai Besi. The location of the site is in the City Centre. 
Figure 1.1 Site Plan of the study

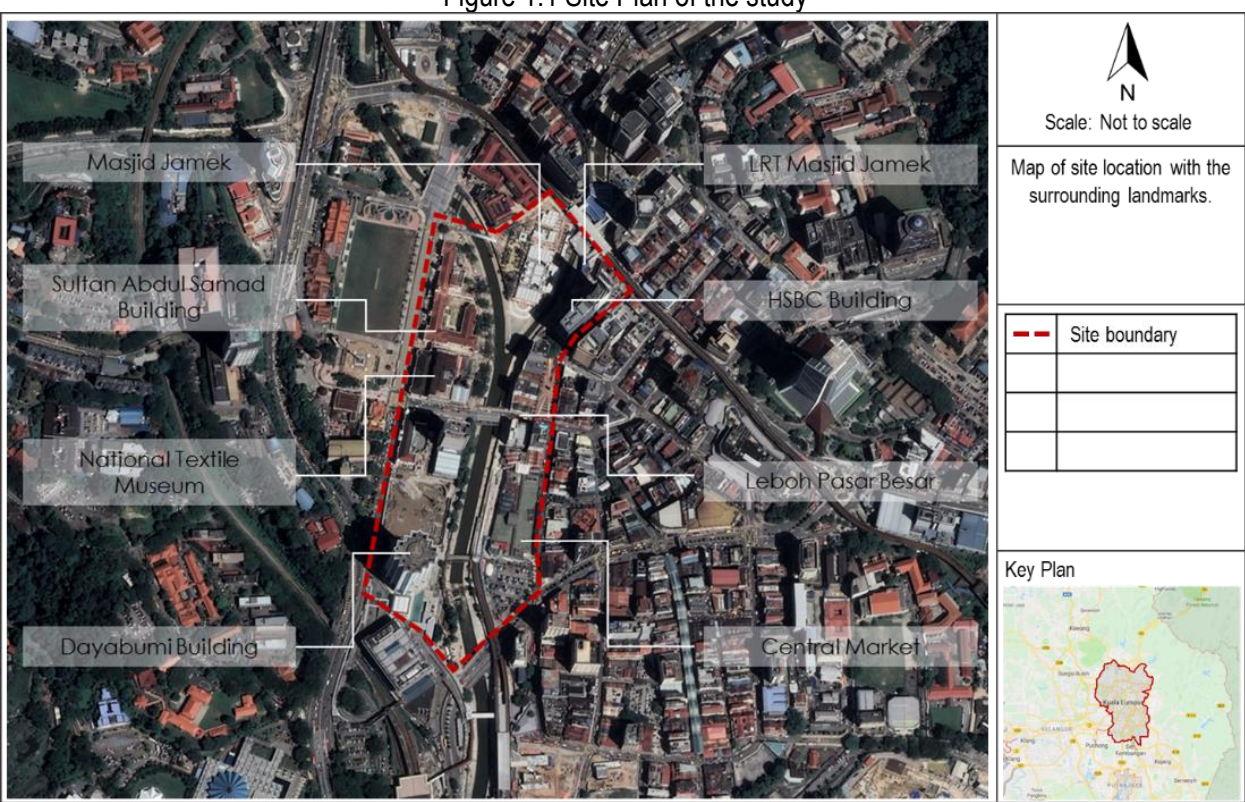

(Source: Google Earth Pro, 2018)

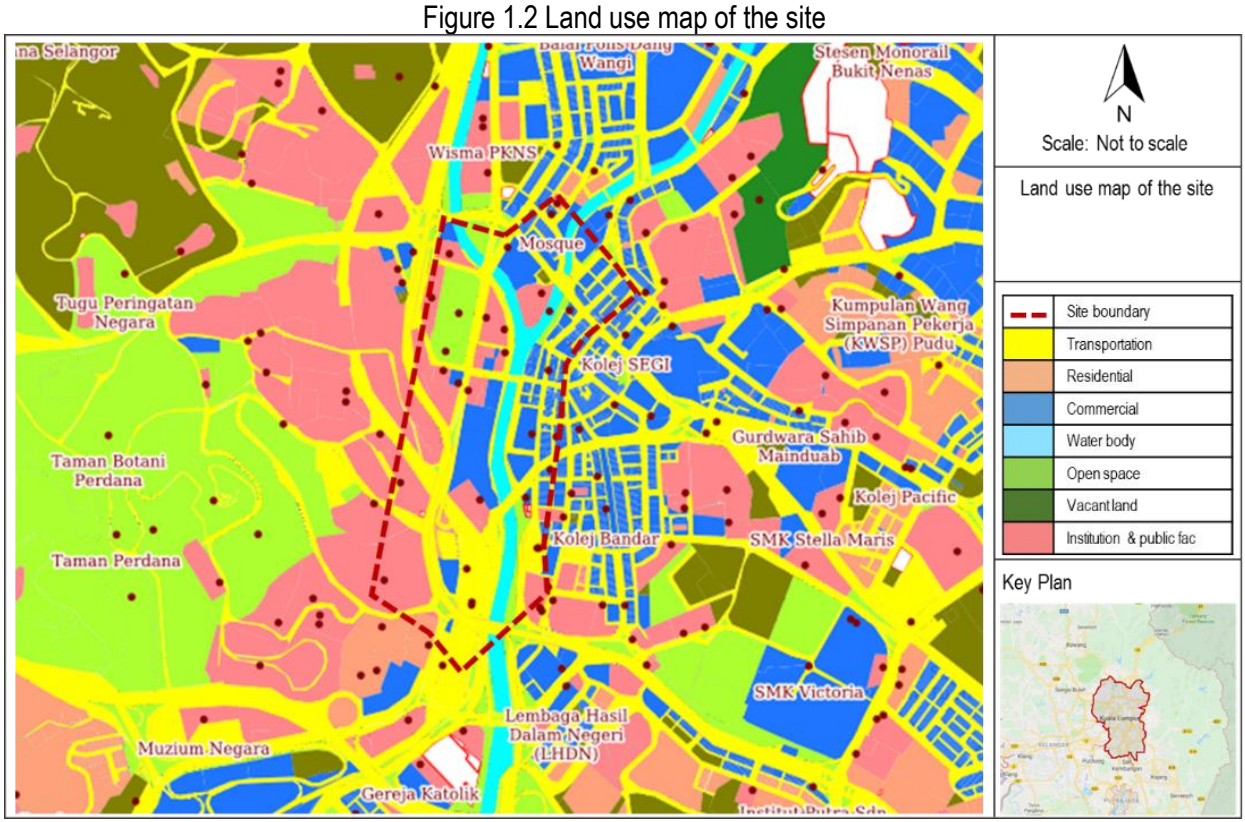

(Source: IPlan Malaysia, 2018)

\subsection{Data Collection}

The types of data collection applied in this research is primary data collection through on-site observation, photo-taking, and questionnaire survey. It was prepared and conducted in both Malay and English for the convenience of the respondents. Likert Scale is used for respondents to rate their opinions based on a scale of one to five, ranging from strongly disagree, disagree, neutral, agree, and strongly agree. The Likert Scale was also applied in the monitoring plan of River Wandle, London, to analyze the users' satisfaction (Redondo. M. D., 2003). The questionnaire consisted of six different parts; the respondent background, awareness regarding the RoL program, and the components of the social impacts of RoL, which are aesthetic values, QoL, and socio-cultural elements, respectively. The last part is the opinions and recommendations of the respondent on the success of the program and plans.

\subsection{Population and Sampling}

The population target for this research is the population in the area of the city center. The zoning of city center Kuala Lumpur consists of commercial with special heritage zones in the surrounding. Therefore, visitors to the site include both local and international tourists. 
Table 1.1 Population and density per sq/km for Kuala Lumpur strategic zones

\begin{tabular}{lllll}
\hline Strategic zones & Area (sq.kms) & Population (2005) & $\begin{array}{l}\text { Density 2005 } \\
\text { (person/sq.kms) }\end{array}$ & $\begin{array}{l}\text { Density 2020 } \\
\text { (person/sq.kms) }\end{array}$ \\
\hline City centre & $\mathbf{1 7 . 7 9 1 5}$ & $\mathbf{1 4 3 , 0 0 0}$ & $\mathbf{8 , 0 3 8}$ & $\mathbf{2 4 5 , 6 0 0}$ \\
\hline Wangsa Maju -Maluri & 46.5858 & 380,300 & 8,163 & 443,712 \\
\hline Sentul-Manjalara & 46.0998 & 344,500 & 7,473 & 445,025 \\
\hline Damansara-Penchala & 47.4531 & 167,100 & 3,521 & 259,078 \\
\hline Bukit Jalil-Seputeh & 43.2288 & 318,300 & 7,363 & 464,271 \\
\hline Bandar Tun Razak-Sg. & & & & \\
Besi & 41.1694 & 266,900 & 6,460 & 10,740 \\
\hline Kuala Lumpur (TOTAL) & 242.3284 & $1,620,100$ & 6,840 & 340,669 \\
\hline
\end{tabular}

(Source: Kuala Lumpur City Plan 2020)

The method of simplifying the sample size was taken from Gill and Johnson (2002), with a 95\% confidence level and $5 \%$ error. The adequate sample size for the given population is 384; however, due to time limitation, 150 sampling was taken. The sampling method used is simple random, where everyone has an equal chance to be selected. The assumptions made from this research is;

1. Everyone who works or visits the area, both local and international, and does not own properties in the area.

2. The distribution of the population for each square kilometer is equal and does not take plot ratio into considerations.

\subsection{Data Analysis}

The methods of data analysis involved in this study are descriptive and inferential analysis by the Statistical Packages for the Social Sciences (SPSS). The descriptive analysis presents the findings in table forms, and inferential analysis involved are chi-square analysis, correlation analysis, and Mean comparisons.

\subsection{Results and Discussion}

\subsection{Relationship between Respondents' Profile and Program Awareness}

The table below shows the summary of the respondent's profile, which consists of approximately half of the population from the age group of 18 to 29 years old and Malay. In terms of education, $78 \%$ had tertiary education. Students constitute the highest percentage of respondents, but the survey represents almost all major occupations. $15 \%$ of international respondents and $60 \%$ of First Time Visitor (FTV) were recorded. These findings showed that respondents who participated in the survey represent the vast spectrum of the population.

Table 1.2 Summary of Respondents' Profile

\begin{tabular}{|c|c|c|c|}
\hline Variables & Category & Frequency $(\mathrm{n})$ & Percentage (\%) \\
\hline \multirow{5}{*}{ Age } & $18-29$ years old & 70 & 46.7 \\
\hline & $30-39$ years old & 45 & 30.0 \\
\hline & 40-49 years old & 21 & 14.0 \\
\hline & $50-59$ years old & 12 & 8.0 \\
\hline & 60 years and above & 2 & 1.3 \\
\hline \multirow{4}{*}{ Ethnicity } & Malay & 67 & 44.7 \\
\hline & Chinese & 34 & 22.0 \\
\hline & Indian & 27 & 17.3 \\
\hline & Others & 22 & 16.0 \\
\hline \multirow{3}{*}{ Educational Level } & High school & 23 & 15.3 \\
\hline & College or university & 118 & 78.7 \\
\hline & Vocational training & 9 & 6.0 \\
\hline \multirow{5}{*}{ Employment } & Students & 53 & 35.3 \\
\hline & Government sector & 50 & 33.3 \\
\hline & Self-employed & 38 & 25.3 \\
\hline & Pensioner & 6 & 4.0 \\
\hline & Unemployed & 3 & 2.0 \\
\hline \multirow{2}{*}{ Origin of visitors } & International visitor & 22 & 14.7 \\
\hline & Local visitor & 128 & 85.3 \\
\hline \multirow{2}{*}{ Visitor's status } & First Time Visitor (FTV) & 91 & 60.7 \\
\hline & Repeat Visitor (RV) & 59 & 39.3 \\
\hline
\end{tabular}

(Source: Primary data: questionnaire survey, 2019)

The questionnaire survey used chi-square to test whether there is a significant relationship between program awareness and other variables. The table below shows the result of the test with a 0.05 level of significance. 
Table 1.3 The Relationship between program awareness and respondent's profile

\begin{tabular}{|c|c|c|c|}
\hline Test & Variables & P-value & Interpretation \\
\hline \multirow{6}{*}{ Pearson Chi-square } & Age group & 0.178 & Not significant \\
\hline & Ethnicity & 0.218 & Not significant \\
\hline & Education level & 0.326 & Not significant \\
\hline & Employment & 0.538 & Not significant \\
\hline & Origin & 0.152 & Not significant \\
\hline & Frequency of visits & 0.000 & Significant \\
\hline
\end{tabular}

${ }^{*} 0.05$ level of significance

(Source: Primary data: questionnaire survey, 2019)

The respondents' program awareness is the same regardless of their age group, ethnicity, education level, employment, and origin. What seems to stand out is the significance of RoL program awareness with the frequency of visits. It shows that their rate of visits influences their knowledge regarding the program. The table below shows the cross-tabulation of the RoL program awareness and their frequency of visits.

\begin{tabular}{llll}
\hline \multirow{2}{*}{ Program Awareness } & \multicolumn{2}{c}{ Visitor's status } & Repeat Visitor \\
\cline { 2 - 4 } & First Time Visitor & 47 & 91 \\
\hline Yes & 44 & 5 & 40 \\
\hline No & 35 & 7 & 19 \\
\hline Not sure & 12 & 59 & 150 \\
\hline Total & 91 & & \\
\hline
\end{tabular}

(Source: Primary data: questionnaire survey, 2019)

Respondents' percentage that voted 'no' was the highest from First Time Visitor. This concludes that the more frequent the visit to the RoL site, the more awareness it brings to the people.

4.2 Social Impacts of RoL Riverfront Regeneration Program based on three elements; Aesthetic Values, QoL and SocioCultural

The three different elements of RoL social impacts are; aesthetic values, QoL, and socio-cultural. The findings are discussed in their mean score to identify which element was influenced the most by the program.

Table 1.5 Respondents answers on the social impacts of RoL

\begin{tabular}{|c|c|c|c|c|c|c|}
\hline Elements & $\begin{array}{l}\text { Strongly } \\
\text { disagree }\end{array}$ & Disagree & Neutral & Agree & Strongly agree & Mean score \\
\hline \multicolumn{7}{|l|}{ Aesthetic value } \\
\hline Positive impact on visual & 4 & 6 & 21 & 65 & 54 & 4.06 \\
\hline $\begin{array}{l}\text { Better paths connection and } \\
\text { proper viewing platform }\end{array}$ & 4 & 5 & 26 & 69 & 46 & 3.99 \\
\hline $\begin{array}{l}\text { Vibrancy to space and music } \\
\text { effect }\end{array}$ & 2 & 13 & 39 & 61 & 35 & 3.76 \\
\hline $\begin{array}{l}\text { Pleasant smell coming out } \\
\text { from the river }\end{array}$ & 55 & 52 & 10 & 22 & 11 & 2.21 \\
\hline \multicolumn{7}{|l|}{ QoL } \\
\hline $\begin{array}{l}\text { Provides encouragement for } \\
\text { new users and activities }\end{array}$ & 2 & 5 & 33 & 65 & 45 & 3.97 \\
\hline $\begin{array}{l}\text { Improves mood, subjective } \\
\text { vitality, and creativity. }\end{array}$ & 2 & 5 & 32 & 76 & 35 & 3.91 \\
\hline $\begin{array}{l}\text { Improves human to water } \\
\text { interaction }\end{array}$ & 4 & 6 & 39 & 68 & 33 & 3.80 \\
\hline \multicolumn{7}{|l|}{ Socio-cultural element } \\
\hline $\begin{array}{l}\text { Revitalize natural and } \\
\text { cultural elements }\end{array}$ & 0 & 8 & 25 & 71 & 45 & 4.03 \\
\hline $\begin{array}{l}\text { Influence distinct image of } \\
\text { Kuala Lumpur }\end{array}$ & 2 & 4 & 32 & 69 & 43 & 3.98 \\
\hline $\begin{array}{l}\text { Increase engagement with } \\
\text { historical building }\end{array}$ & 2 & 7 & 36 & 68 & 37 & 3.87 \\
\hline
\end{tabular}

The mean value of 4.06 indicates that the program has proven to improve the visual of the surrounding landscape. Also, this finding suggests that Silva, Saraiva, Ramos, \& Bernado (2005) were right regarding the evaluation of the aesthetic from the viewpoint of people where nature and spaces can influence the preference of an individual. The mean value is followed by 3.99 and 3.76 for better paths connection, viewing platform, and adding vibrant to space and sound effects, respectively. 


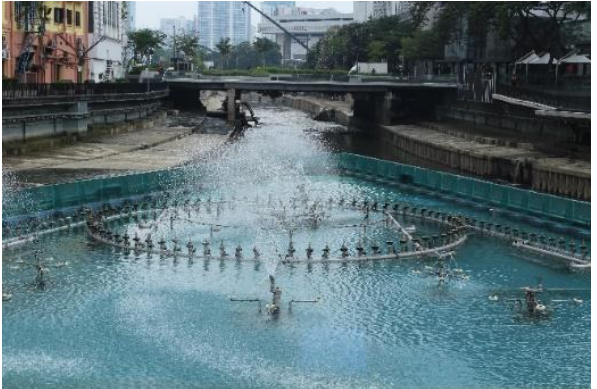

(a)

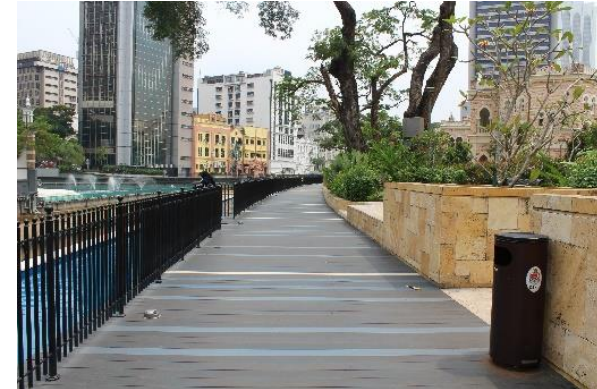

(b)

Figure 1.3 (a) Viewing platform and (b) pedestrians along the river

(Source: Author)

Based on the survey, the pleasantness of smell from the river scored a low mean; 2.21, indicating the respondent's disagreement with the statement. This finding shows that the program did not manage to eliminate the odor from the river. However, it is a very subjective element of the studies as it depends on the level of tolerance of the people. The next item that was studied is QoL. Based on the table above, the highest score for the mean value is 3.97 reflecting the respondents' agreement towards the encouragement of new users and activities. Recreation activities and social interactions have improved the QoL since the implementation of the RoL program. Keles (2012) supported as she stated that one of the factors contributing to the improvement or worsening of QoL is the ability to access environmental infrastructure and services. Whenever there is inadequate access to the service or system, it leads to poor QoL. Next, the respondents agreed that RoL has improved moods, subjective vitality, and creativity. The physical improvement of the area has open higher opportunities for leisure activities and socialize, which leads to the fulfillment of psychological needs (Brajsa-Zganec, Merkas, \& Sverko, 2011; Rosli et al. 2018). Besides, RoL is proven to improve human to water interaction by scoring a mean value of 3.80. Sairinen \& Kumpulainen (2006 agreed that the interaction of humans to water gives out the therapeutic experiences, visual messages, physical touch, tastes, voices, moving in the space, sense of transition, which contributes to the enhancement of QoL.

The last impact studied is on the socio-cultural element. Based on the table, the respondents agreed that RoL has successfully revitalized the natural and cultural aspects of the area. The integration between the two components is used as a medium to promote the urban waterfront regeneration program. Next, the findings suggest that the respondents are well aware that the program has created a distinct image of Kuala Lumpur. The integration of Klang River and the mosque of Masjid India Riverfront create a more distinct concept of an area. The area would be more highly visible, recognizable, interconnected with better and clear paths. Lastly, the result from the table indicates that RoL managed to increase the community's engagement with the historical building in the area. The site is a historic core of Kuala Lumpur, which is a valuable tourist spot and has encompassed most of the early commercial, residential, and administrative buildings. RoL program promotes the unique architecture of the historic building to both local and international visitors.

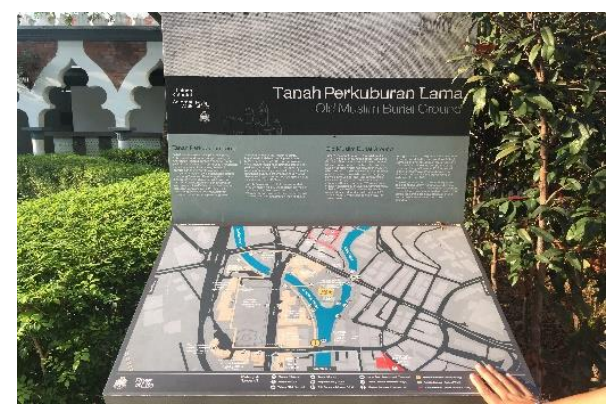

(a)

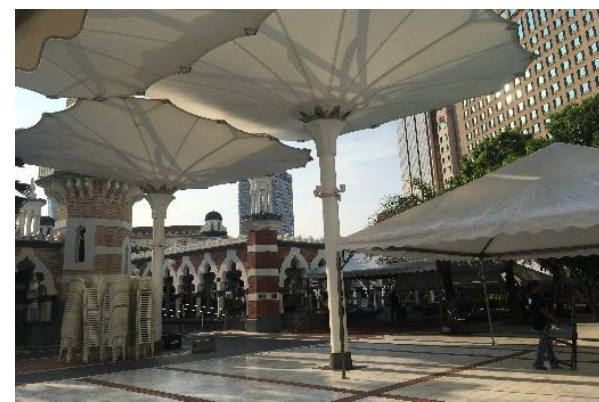

(b)

Figure 1.4 (a) information about the historical building and (b) renewal of Masjid Jamek (Source: Author)

\subsection{Public's Opinion and Recommendations}

The questionnaire survey required the respondents to answer on the opinions and recommendations part for future research. This part is essential and beneficial as it can act as a critical suggestion in achieving the best course of action in the case of RoL.

Table 1.6 Opinions and recommendations of respondents

\begin{tabular}{llllll}
\hline Elements of the socio-cultural & $\begin{array}{l}\text { Strongly } \\
\text { disagree }\end{array}$ & Disagree & Neutral & Agree & Strongly agree \\
\hline The program is a success. & 4 & 7 & 45 & 25 & 3.69 \\
\hline $\begin{array}{l}\text { Interested in participating in } \\
\text { current and future efforts of } \\
\text { river restoration. }\end{array}$ & 4 & & 37 & 61 & 33 \\
\hline $\begin{array}{l}\text { Likely to recommend the river } \\
\text { restoration efforts and } \\
\text { programs to friends and family. }\end{array}$ & 2 & 15 & & & 3.69 \\
\hline
\end{tabular}


The survey revealed that the RoL program was a success, and the respondents were likely to support future efforts for riverfront restoration. More than half of the respondents were positive, which leads to the possibility of them to put in the right word for the future waterfront restoration program. The respondents suggested strengthening the integration and cooperation between stakeholders as one of the measures to improve the program. It includes the Local Authority, developers, and local people. Other than that, a nighttime event can be done to promote the nightscape created by the Blue Pond in RoL, aside from encouraging the promotion for tourism activity. The existing tourism activity in the area is the Colonial Walk as part of the city walking trails to visit the historical landmarks in Kuala Lumpur alongside the river. Lastly, a volunteering program among the students can benefit from educating and raising awareness among the students. The youths' participant is among the fundamental component to achieve the sustainability of the environment.

\subsection{Limitations of the Study}

This research is limited to the aspect of social, anything beyond the subject matter is not covered. Next, this research will only cover the area of $\mathrm{KLCH}$, which, consists of the three primary nodes in the area of Masjid Jamek, Merdeka Square, and Central Market in Kuala Lumpur.

\subsection{Conclusion \& Recommendations}

In conclusion, the more frequent the visit to the RoL site, the more awareness it brings to the people, and 59 respondents were still not aware and not sure about the program. Next, respondents responded positively to the social impacts of RoL. However, 2.21 mean value was scored, indicating the program did not manage to eliminate the odor from the river. Lastly, the findings from the survey indicate that the people agreed that the program was a success, they were interested in joining and recommended to friends and families regarding the current and future efforts of river restoration. The respondents suggested to strengthen integration among stakeholders, to promote night time events, and to encourage youths volunteering program. The local government has to identify both point and non-point source pollution. It is crucial to ensure the septic tanks in the residential areas do not discharge the water directly and untreated to the river. Significant investment to modernize sewage treatment infrastructure is crucial to avoid untreated water from flowing into the main stream. Next, increasing the number of regulations for waterfront development is one of the measures in the aspect of management and planning. Comprehensive and thorough guidelines and regulations must be established to improve the overall growth and success of this particular project. Besides, the guidelines produced must be site-specific rather than generalizing the cases. Lastly, the ungazzetted guidelines lead to the inefficient implementation of enforcement towards a sustainable waterfront. One of the most critical phases in restoration efforts is monitoring. Appropriate monitoring, standardize monitoring guidelines, and funding are all parts of the management phase. In the era of industrial revolution 4.0, the use of a technological approach in monitoring efforts is encouraged for effective monitoring. Environmental education is a concept encompassing a vision of culture that seeks to empower people of all ages to assume responsibility for creating a sustainable future. Therefore, an early and appropriate environmental education is vital to improve the community's sensitivity towards the environment and its allied problems. There will be challenges to balance the social, environmental, and financial of the restoration efforts, but the results of the initiative could lead to significant economic, QoL, and environmental sustainability.

\section{Acknowledgment}

We want to express our gratitude towards everyone who has participated in the survey.

\section{References}

Brajša-Žganec, A., Merkaš, M., \& Šverko, I. (2011). Quality of life and leisure activities: How do leisure activities contribute to subjective well-being?. Social Indicators Research, 102(1), 81-91.

Deng, X., Xu, Y., Han, L., Song., Yang, L., G., \& Wang, Y. (2015). Impacts of urbanization on river systems in the Taihu Region, China. Water, 7(4), 1340-1358.

Garau, C., \& Pavan, V. (2018). Evaluating urban quality: indicators and assessment tools for smart sustainable cities. Sustainability, 10(3), 575.

Gill, J., \& Johnson, P. (2002). Research methods for managers. Sage.

Glasson, J., \& Wood, G. (2009). Urban regeneration and impact assessment for social sustainability. Impact Assessment and Project Appraisal, 27(4), 283-290.

Jun, K. S., \& Kim, J. S. (2011). The four major rivers restoration project: impacts on river flows. KSCE Journal of Civil Engineering, 15(2), 217-224.

Keles, R., (2012), the Quality of Life of the Environment, Asia Pacific International Conference on Environment-Behavior Studies, Salamis Bay Conti Resort Hotel, Famagusta, North Cyprus.

Krause, C.L., 2001. Our visual landscape - Managing the landscape under special consideration of visual aspects. Landscape Urban Plann, 54: $239-254$.

Önen, M. (2007). Examinatıon Rivers' Recreational Potential As An Urban Coastal Space: Case Study, Eskişehır Porsuk Creek and istanbul Kurbağalıdere (Doctoral dissertation, Master Thesis, Istanbul Technical University, Institute of Science And Technology, 204 p., Istanbul). 
Palermo, L. (2014). The role of art in urban gentrification and regeneration: aesthetic, social and economic developments. IL CAPITALE CULTURALE. Studies on the Value of Cultural Heritage, (10), 521-545.

Rabe, N. S., Osman, M. M., Bachok, S., Rosli, N. F., \& Abdullah, M. F. (2018). Perceptual study on conventional quality of life indicators. PLANNING MALAYSIA JOURNAL, 16(5), 304.

Redondo. M. D., Social Impact Assessment For River Restoration: a More Sustainable Perspective, (Unpublished Master's dissertation), University of East Anglia

Rosli, N. F., Rabe, N. S., Osman, M. M., \& Abdullah, M. F. (2018). Perception of quality of life among community in Selangor. PLANNING MALAYSIA JOURNAL, 16(6).

Silva, J. B., Saraiva, M. G., Ramos, I. L., \& Bernardo, B. (2005). Methodology of aesthetic evaluation of rivers in urban context. In Proceedings of Urban River Rehabilitation Conference, Dresden, 5-6

Streimikiene, D. (2015). Environmental indicators for the assessment of quality of life. Intellectual Economics, 9(1), 67-79.

Timur, U. P. (2013). Urban waterfront regenerations. In Advances in landscape architecture. IntechOpen.

Tumbde, D. (2005). Conceptual model for economically viable urban riverfront revitalization in United States (Doctoral dissertation, University of Cincinnati).

Wu, J., He, C., Huang, G., \& Yu, D. (2013). Urban landscape ecology: Past, present, and future. In Landscape ecology for sustainable environment and culture (pp. 3753). Springer, Dordrecht.

Zhang, L. (2002). An evaluation of an urban riverfront park, Riverfront Park, Spokane, Washington: experiences and lessons for designers. 